\title{
Implied Rights of Action to Enforce Civil Rights: The Case for a Sympathetic View
}

In the last fourteen years Congress has enacted a number of statutes that are intended to protect civil rights but that do not explicitly create a private right of action. ${ }^{1}$ Federal courts have generally considered implication of private rights ${ }^{2}$ a necessary or useful tool in the enforcement of these statutes. ${ }^{3}$ The courts, in finding implied rights of action under civil rights statutes, are simply following a long tradition that favors implying rights of action for parties asserting their own civil rights. ${ }^{4}$

This tradition is threatened by the Supreme Court's 1975 decision in Cort v. Ash, which promulgated several criteria "relevant" to the implication question. ${ }^{6}$ The Cort opinion culminated a series of de-

1. These statutes include Title VI of the Civil Rights Act of 1964, Pub. L. No. 88-352, $\$ \$ 601-605,78$ Stat. 252 (codified at 42 U.S.C. $\$ \$ 2000 \mathrm{~d}$ to 2000d-4 (1970)); Voting Rights Act of 1965 , Pub. L. No. $89-110, \$ 5,79$ Stat. 439 (codified as amended at 42 U.S.C. $\$ 1973 \mathrm{c}$ (1970)); Title IX of the Education Amendments of 1972, Pub. L. No. 92-318, 86 Stat. 373 (codified as amended at 20 U.S.C. $\$ \$ 1681-1686$ (Supp. V 1975)); Rehabilitation $\Lambda$ ct of 1973, Pub. L. No. 93-112, $\$ 504,87$ Stat. 394 (codificd as amended at 29 U.S.C. \$ 794 (Supp. V 1975)). Congressional enactments that by their terms guarantec civil rights but do not provide for private remedies are not a new development. See, e.g., Civil Rights Act of 1866 , ch. $31, \$ 1,14$ Stat. 27 (codified at 42 U.S.C. $\$ 1982(1970)$ ).

2. The implication of a private right of action has been defined as "the extension of a civil remedy to one injured by another's breach of a statute or regulation not providing for such relief." Note, Implying Civil Remedies From Federal Regulatory Stalutes, 77 Harv. L. Rev. 285, 285 (1963). The problem of deciding when to imply the existence of a private right of action might have been avoided had Congress followed Professor Wechsler's suggestion in the 1940s and enacted an enabling statute providing guidelines for implication of causes of action by the federal courts. See Wechsler, Federal Jurisdiction and the Revision of the Judicial Code, 13 LAw \& Contemp. Pron. 216, 225, 241 (1948). Congress apparently has never acted on this suggestion.

3. See, e.g., Allen v. State Bd. of Elections, 393 U.S. 544, 556-57 (1969) (voting rights); Lloyd v. Regional Transp. Auth., 548 F.2d 1277, 1284-87 ( 7 th Cir. 197\%) (rights of handicapped); Fitzgerald v. Pan Am. World Airways, 229 F.2d 499, 501-02 (2d Cir. 1956) (nondiscrimination on airlines); Piascik v. Cleveland Museum of Art, 426 F. Supp. 779, 780 n.l (N.D. Ohio 1976) (sex discrimination). Some commentators have agreed. Sce, e.g., Albert, Standing to Challenge Administrative Action: An Inadequate Surrogate for Claim for Relief, 83 Yale L.J. 425, $451-56$ (1974); SheIton \& Berndt, Sex Discrimination in Vo. cational Education: Title IX and Other Remedies, 62 CALIF. L. REv. 1121, 1149-59 (1974).

4. See pp. 1387-92 infra.

5. 422 U.S. 66 (1975).

6. Id. at 78 . 
cisions, outside the civil rights area, that have redefined the circumstances in which federal courts should imply private rights of action. ${ }^{7}$ Since the Cort decision, some lower federal courts have applied its criteria as a restrictive standard in testing for the existence of a private right of action under civil rights statutes. ${ }^{8}$ In probably the most farreaching of these decisions, Cannon v. University of Chicago, ${ }^{8}$ the Seventh Circuit held that no private right of action exists under Title IX of the Education Amendments of 1972,10 which forbids discrimination on the basis of sex in most federally funded educational programs.

7. See pp. 1381-86 infra. The increasingly restrictive view of the implication doctrine parallels an increasingly restrictive approach by the Supreme Court to the issue of standing, a question related to the first criterion of Cort v. Ash, 422 U.S. 66, 78 (1975), that legislation be enacted for the plaintiff's "especial benefit." Compare Schlesinger v. Reservists Comm. to Stop the War, 418 U.S. 208, 220-22 (1974) (standing depends on whether plaintiff suffers "concrete injury" by governmental action) and United States v. Richardson, 418 U.S. 166, 175-78 (1974) (injury must not be common to all members of public) with Flast v. Cohen, 392 U.S. 83, 101 (1968) (standing depends on whether plaintiff has "personal stake" in outcome and whether his legal interest is sufficiently adverse to that of defendant). One commentator has examined three of the Court's most recent standing decisions, Simon v. Eastern Ky. Welfare Rights Organization, 426 U.S. 26 (1976); Warth v. Seldin, 422 U.S. 490 (1975); and Linda R.S. v. Richard D., 410 U.S. 614 (1973), and concluded that they have further narrowed the scope of standing, so that even before the court can reach the merits the plaintiff must show that the harm he alleges is certain, and not mercly probable, and that the governmental action complained of has a causal connection to the harm. Davis, Slanding, 1976, 72 Nw. U.L. REv. $69,72.74$ (1977).

Some cases suggest that there are circumstances in which there is little difference between speaking in terms of an implied right of action and standing. See, e.g., National R.R. Passenger Corp. v. National Ass'n of R.R. Passengers, 414 U.S. 453, 467 (1974) (Douglas, J., dissenting). But the two concepts are logically distinct, as the majority in this case noted. Id. at 456 (court need reach standing question only if private right cxists). Professor Albert has pointed out that the standing question may form a component of the cause of action but does not provide the cause of action itself. Albert, supra note 3 , at $428-29$. The standing inquiry focuses on whether the plaintiff is a proper one to assert the cause of action; it does not answer the prior question whether a cause of action exists. See Comment, Private Rights of Action Under Amtrak and Ash: Some Implications for Implication, 123 U. PA. L. REV. 1392, 1408-11 (1975) (standing focuses on whether proper party asserts claim; implication focuses on whether private action proper).

8. See, e.g., Cannon v. University of Chicago, 559 F.2d 1063, $1071-75$ (7th Cir. 1976), aff'd on rehearing, 559 F.2d 1077 (7th Cir. 1977), petition for cert. filed, 46 U.S.L.W. 3438 (U.S. Dec. 28, 1977) (No. 77-926) (no private right under Title IX of Education Amendments of 1972, 20 U.S.C. $\$ \S 1681-1686$ (Supp. $V$ 1975), to challenge professional school admissions as discriminatory on basis of sex); People's Hous. Dev. Corp. v. Gity of Poughkeepsie, 425 F. Supp. 482 (S.D.N.Y. 1976) (no private right under Housing and Community Development Act of 1974, $\$ \S 101(c), 109,42$ U.S.C. $\$ \S 5301$ (c), 5309 (Supp. $\mathrm{V}$ 1975), to challenge racial discrimination in housing); Cape v. Tennessee Secondary School Athletic Ass'n, 424 F. Supp. 732 (E.D. Tenn. 1976), rev'd on other grounds, 563 F.2d 793 (6th Cir. 1977) (lower court found no private right under Title IX; court of appeals did not address question).

9. 559 F.2d 1063 (7th Cir. 1976), aff'd on rehearing, 559 F.2d 1077 (7th Cir. 1977), petition for cert. filed, 46 U.S.L.W. 3438 (U.S. Dec. 28, 1977) (No. 77-926).

10. 20 U.S.C. \$\$ 1681-1686 (Supp. V 1975). 
This Note contends that insofar as Cort is read as restricting the test for implication, its reasoning should not mechanically be applied to the area of civil rights law. The Note identifies reasons of both tradition and policy for reading the Cort criteria as favoring implication where the broad purpose of protecting civil rights underlies a statute. Finally, the Note illustrates the proper application of Cort in the civil rights area by using it to argue that a private right of action exists under Title IX.11

\section{Cort v. Ash and Two Lines of Implication Cases}

Although the federal courts have been attempting for more than sixty years to develop a coherent doctrine of implication, ${ }^{12}$ the Supreme Court made no explicit attempt to summarize the criteria for implying private rights until its 1975 decision in Cort $v . A s h{ }^{13}$ The Cort decision, which set out four factors "relevant" to the implication question, ${ }^{14}$ has been viewed as enunciating a restrictive view of the implication doctrine. ${ }^{15}$ The Cort criteria were based on principles drawn from the dominant strand of Supreme Court precedent dealing with implication. ${ }^{16}$ But it remains unclear what effect Cort will have on a recurrent but less-noted theme in implication

11. Although the Cannon court held that no private right of action exists under Title IX, at least one federal court has reached the opposite conclusion. Piascik v. Cleveland Museum of Art, 426 F. Supp. 779, 780 n.I (N.D. Ohio 1976). A federal magistrate has suggested, in dictum, his strong disagreement with the Cannon result. Alexander v. Yale, C. No. N-77-277, slip op. at 6-10 (D. Conn. Dec. 21, 1977). See Commentary, Scs Discrimination in Athletics: Conflicting Legislative and Judicial Approaches, 29 AL4. L. Rev. 390, 415 -18 (1978) (contrasting Cannon and Piascik). Compare Shelton \& Berndt, supra note 3, at $1149-59$ (private right of action ought to be implied) with Note, Taxing Sex Discrimination: Revoking Tax Benefits of Organizations Which Discriminate on the Basis of Sex, 1976 ARız. Sr. L.J. 641, 661 (stating without argument that no private right exists).

12. The first federal decision explicitly dealing with the implication doctrine appears to have been Texas \& Pac. Ry. Co. v. Rigsby, 241 U.S. 33 (1916). See pp. 1382-83 infra. The Court announced what almost seemed a "test" for implication in Wyandotte Transp. Co. v. United States, 389 U.S. 191, 202 (1967). See note 37 infra (discussing this "test").

13. 422 U.S. 66 (1975).

14. Id. at 78 .

15. See, e.g., Climan, Civil Liability Under the Credit-Regulation Provisions of the Securities Exchange Act of 1934, 63 CoRnell L. REv. 206, 261 (1978); McMahon \& Rodos, Judicial Implication of Private Causes of Action: Reappraisal and Retrenchment, 80 Dick. L. REv. 167, 167-68, 177, 184 (1976); Note, Implication of Private Actions From Federal Statutes: From Borak to Ash, 1 J. CoRP. L. 371, 371-72, 380-89 (1976). The judgment as to how restrictive the Cort test actually is will have to await further judicial explication. See pp. 1386-87 infra.

16. See pp. 1381-86 infra. 
cases that favors implication of private remedies where parties assert statutorily protected civil rights. ${ }^{17}$

\section{A. Genesis of the Cort Criteria}

The approach adopted in Cort can best be understood by comparing the specific criteria promulgated in that case with the precedents from which they were drawn. Cort $v$. Ash was a derivative damage action by a stockholder of Bethlehem Steel Corporation against the corporation's chairman for violating a criminal statute ${ }^{18}$ that prohibited corporate expenditures in connection with a presidential election. The principal question for decision was whether a private right of action should be implied under the statute. ${ }^{19}$ In declining to find a private right, the Court, through Justice Brennan, listed four factors as "relevant" to the determination:

First, is the plaintiff "one of the class for whose especial benefit the statute was enacted," . . . that is, does the statute create a federal right in favor of the plaintiff? Second, is there any indication of legislative intent, explicit or implicit, either to create such a remedy or to deny one? . . . Third, is it consistent with the underlying purposes of the legislative scheme to imply such a remedy for the plaintiff? . . . And finally, is the cause of action one traditionally relegated to state law, in an area basically the concern of the States, so that it would be inappropriate to infer a cause of action based solely on federal law?

Although the criteria appear neutral, the Court's application of them made clear that private rights of action would not lightly be implied. ${ }^{21}$ An analysis of the precedent supporting each criterion makes clear

17. For the purposes of this Note, a civil rights statute is one enacted to prohibit discrimination against an identifiable class or group on the basis of an immutable characteristic such as race, sex, or handicap. A party asserting his or her civil rights is claiming to have been subjected to forbidden discrimination on such a basis.

18. Act of June 25, 1948, as amended, 18 U.S.C. $\$ 610$ (1970) (repealed 1976).

19. 422 U.S. at 68-69.

20. Id. at 78 (citations omitted) (emphasis in original).

21. The Court held at the outset that the intent to protect the plaintiff's class (corporate stockholders) "was at best a subsidiary purpose" of the statute, id. at 80 , and cited legislative history to buttress that conclusion, $i d$. at $80-83$. The Court then noted that the legislative history was silent as to any intent to create a private right and took the legislative silence as support for its finding that no private right existed. The claim that such a private right was consistent with the legislative scheme was rejected in one paragraph, again with citations to the legislative history. The Court concluded that an implied private remedy would indeed conflict with a traditional remedy under state law. Id. at $82-84$. 
why the Cort opinion marks the culmination of the dominant strand of implication cases. ${ }^{22}$

The first Cort criterion focuses on whether the plaintiff is a member of the class "for whose especial benefit the statute was enacted."23 This criterion originated in Texas of Pacific Railway Co. v. Rigsby, ${ }^{24}$ the first modern case in which the Supreme Court found a private right to sue under a statute not expressly providing one. ${ }^{25}$ The plaintiff, a railroad worker, sued his employer after he was injured due to the employer's violation of a safety statute that prescribed only criminal penalties. ${ }^{26}$ The Court, in finding a private right to sue, pointed out that the statute's "principal object" was the protection of railroad workers and that the common law doctrine of statutory torts ${ }^{27}$ there-

22. Throughout this Note, references are made to the "dominant" or "major" strand of implication cases. This is simply a generic term to tie together the great bulk of implication cases, which, the Note argues, have only one thing in common: they are not civil rights cases. See note 17 supra. This major strand is characterized by the approach described in this subsection.

23. 422 U.S. at 78.

24. 241 U.S. 33 (1916).

25. Arguably, the implication doctrine in the federal courts may be traced to the landmark decision in Marbury v. Madison, 5 U.S. (I Cranch) 137 (1803). Chief Justice Marshall set forth one of the questions for decision: "If [Marbury] has a right, and that right has been violated, do the laws of his country afford him a remedy?" Id. at 162. He answered his own question: "The government of the United States has been emphatically termed a government of laws, and not of men. It will certainly cease to deserve this high appellation, if the laws furnish no remedy for the violation of a vested legal right." Id. at 163. After Marbury, but still 42 years prior to Rigsby, the Court stated that "[a] general liability created by statute without a remedy may be enforced by an appropriate common-law action." Pollard v. Bailey, 87 U.S. (20 Wall.) 520, 527 (1874) (dictum). Furthermore, even though the Supreme Court had not applied the implication doctrine prior to Rigsby, its existence was apparently not in question. See, e.g., Thayer, Public Wrong and Private Action, 27 HARv. L. Rev. 317, 328 (1914).

26. Suit was filed under the Federal Safety Appliance Acts, Act of March 2, 1893, ch. 196, 27 Stat. 531 (1893) (current version at 45 U.S.C. $\$ \S 1-16$ (1970)), by an employee injured while working on a railroad car. The employer contended that the employee had no private right of action and that the Act did not apply under the facts of the case. 241 U.S. at 37-39. The Court found that the private right of action existed and also held for the employee on the merits. Id. at $42-43$. The Court subsequently held that the existence of state remedies could eliminate the need for a common law action in such a case. Moore v. Chesapeake \& O. Ry. Co., 291 U.S. 205, 214-17 (1934); Tipton v. Atchison, T. \& S.F. Ry. Co., 298 U.S. 141, 147-48 (1936). See generally P. Bator, P. Mishinin, D. Shapiro \& H. Wechsler, Hart \& Wechsler's The Federal Courts and the FEDERAL System 798 (2d ed. 1973).

27. The statutory tort doctrine has been defined in relation to the law of negligence as permitting a court to adopt "as the standard of conduct of a reasonable man" the requirements of a statute intended:

(a) to protect a class of persons which includes the one whose interest is invaded, and

(b) to protect the particular interest which is invaded, and

(c) to protect that interest against the kind of harm which has resulted, and

(d) to protect that interest against the particular hazard from which the harm results.

Restatement (SECOND) of Torts $\$ 286$ (1965). See generally W. Prosser, The LAw of TonTs $\$ 36$ (4th ed. 1971). 
fore gave rise to the private right of action.28

Many lower courts subsequently came to view the "especial benefit" criterion as a reflection of the "statutory tort" doctrine and as the only prerequisite to implying a private right of action. ${ }^{29}$ The Supreme Court permitted this broad view to stand almost without challenge ${ }^{30}$ until the 1950s and 1960s, when it added the idea that courts should search for a legislative intent to create or to deny a private right of action and, further, that the implication ought to be consistent with effectuating the congressional purpose, that is, with righting the wrong that Congress sought to address. ${ }^{31}$ This limited search for congressional intent and the broader question of the underlying purpose or "goal" would become the second and third Cort criteria. ${ }^{32}$ The Court began to examine the consistency of implication with

28. 241 U.S. at $39-40$. The Court did not explicitly characterize the case as one of "statutory tort," preferring to call it an application of the maxim $u b i$ jus, ibi remedium (where there is a right, there is a remedy). But the Court did apply statutory tort reasoning. Id.; cf. Wyandotte Transp. Co. v. United States, 389 U.S. 191, 202 (1967) (conclusion in Rigsby "was in accordance with a general rule of the law of torts"). See also note 29 infra (citing sources on and discussing "statutory tort" doctrine).

29. See, e.g., Howard v. Furst, 140 F. Supp. 507, 510 (S.D.N.Y.), aff'd, 238 F.2d 790 (2d Cir. 1956), cert. denied, 353 U.S. 937 (1957) (criminal statute enacted for benefit of class implies private right of action in class member absent evidence to contrary); Kardon v. National Gypsum Co., 69 F. Supp. 512, 513-14 (E.D. Pa. 1946) (disregard of statutory command is "a wrongful act and a tort" and actionable unless contrary legislative intent "should appear very clearly and plainly"). The commentators have often agreed. See, e.g., 2 L. Loss, Securities Reglition 942.43 (2d ed. 196I); Morris, The Relation of Criminal Statutes to Tort Liability, 46 Harv. L. REv. 453, 453 (1933). But see Note, The Use of Criminal Statutes in the Creation of New Torts, 48 Colum. L. Rev. 456, 456 (1948) (statutory tort doctrine "has not won universal acceptance").

For a discussion of whether implication under the "statutory tort" doctrine should be limited to those statutes enacted to prohibit actions previously covered by common law rules of negligence, compare Ruder, Civil Liability Under Rule 10b-5: Judicial Revision of Legislative Intent?, 57 Nw. U.L. REv. 627, 631-35 (1963), with Joseph, Civil Liability Under Rule 10b-5-A Reply, 59 Nw. U.L. REv. 171, 172-74 (1964).

30. But see Texas \& N.O.R.R. v. Brotherhood of Ry. \& S.S. Clerks, 281 U.S. 548, 562-67 (1930) (using legislative history and purpose to provide evidence of intent); Pennsylvania R.R. Sys. \& Allied Lines Fed'n No. 90 v. Pennsylvania R.R. Co., 267 U.S. 203, 216 (1925) (implying that legislative intent is relevant). The Court also noted in dictum that federal courts are not "restricted to the remedies available in state courts" to enforce "federal rights." Board of County Comm'rs v. United States, 308 U.S. 343, 350 (1939). And in its landmark decision in Bell v. Hood, 327 U.S. 678 (1946), the Court strongly implied that in the proper circumstances a cause of action might be implied under the Fourth or Fifth Amendment. Id. at 683.84. Such a purely constitutional cause of action was finally permitted under the Fourth Amendment in Bivens v. Six Unknown Named Agents of the Fed. Bureau of Narcotics, 403 U.S. 388 (1971).

31. See note 35 infra (discussing cases).

32. See Cort v. Ash, 422 U.S. 66, 78, 84 (1975). Well before the Court explicitly incorporated legislative intent and legislative purpose into the implication test as distinct criteria, Justice Frankfurter suggested that the distinction between them was a useless one. Frankfurter, Some Reflections on the Reading of Statutes, 47 Colum. L. Rev. 527, 538-40 (1947). 
intent and purpose when faced with parties asserting private rights under statutes that had created sophisticated economic regulatory schemes. In both the 1951 case of Montana-Dakota Utilities Co. $v$. Northwestern Public Service Co. ${ }^{33}$ and the 1959 case of T.I.M.E. Inc. v. United States, ${ }^{34}$ the Court refused to imply judicially enforceable rights under regulatory statutes where there was no evidence of intent to create private rights of action and where it was clear that implication would interfere with the functioning of the administrative agency charged with enforcing the statutes. ${ }^{35}$ By 1964, when the Court decided J.I. Case Co. v. Borak, ${ }^{36}$ it was satisfied that implication would not interfere because Congress had intended to create private rights in some circumstances and because, in any case, courts should be alert to provide those remedies "necessary to make effective the congressional purpose."37

33. 341 U.S. 246 (1951).

34. 359 U.S. 464 (1959).

35. In Montana-Dakota the plaintiff claimed that the Federal Power Act, 16 U.S.C. $\S \S 791 \mathrm{a}-825 \mathrm{r}(1940)$ (current version at 16 U.S.C. $\$ \S 791 \mathrm{a}-828 \mathrm{c}(1970)$ ), created a private right of action to recover damages from unreasonable utility rates. The Court observed that the plaintiff's dilemma was to "avoid Scylla without being drawn into Charybdis": either the action was for common law fraud and deceit, meaning it should be pursued under state law, or it was for rates in excess of those permitted by the Act, in which case the Federal Power Commission had exclusive ratemaking authority. 341 U.S. at 250-53. In either case, the asserted right was not a major goal of the legislation, because there was no "right" conferred by the statute except "the right to the rate which the Commission files or fixes." Id. at 251.

The T.I.M.E. Inc. case raised the analogous question whether the Motor Carrier Act of 1935, as amended, 49 U.S.C. $\$ \$ 301-327$ (1970 \& Supp. V 1975), created "a judicially enforceable right in a shipper to be free from the exaction of unreasonable charges." 359 U.S. at 468 . The Court cited Montana-Dakota in support of its finding that the statute did not create such an enforceable right. Id. at 469 . The Court then reinforced this conclusion by looking into the legislative history and agency interpretations to find evidence against congressional intent to create such a right. $I d$. at 469-72. For a general view of the state of implication law around the time of these decisions, see Note, supra note 2.

36. 377 U.S. 426 (1964).

37. Id. at 433. It has been suggested that the Court in Borak was somewhat disingenuous in calling the right to sue "necessary," because other remedics were available. Dellinger, Of Rights and Remedies: The Constitution as a Sword, 85 HARv. L. REv. 1532, I550-51 (1972). The Supreme Court would later suggest that Borak and Rigsby may have applied the same reasoning process:

In those cases we concluded that criminal liability was inadequate to ensure the full effectiveness of the statute which Congress had intended. Because the interest of the plaintiffs in those cases fell within the class that the statute was intended to protect, and because the harm that had occurred was of the type that the statute was intended to forestall, we held that civil actions were proper. That conclusion was in accordance with a general rule of the law of torts.

Wyandotte Transp. Co. v. United States, 389 U.S. 191, 202 (1967). Although this amounts in substance to a restatement of the statutory tort doctrine, it is unlikely that the Court intended to adopt that doctrine as the sole test for implication. The Court apparently has 
The examination of intent and purpose before deciding whether to imply private rights of action was not limited to cases involving economic regulatory statutes. The Court evidenced a similar concern in the early 1960s in deciding whether to imply private rights under statutes governing the issuance of subpoenas ${ }^{38}$ and regulating labormanagement relations. ${ }^{30}$

In the 1970s the Court decided two more cases dealing with the evidentiary weight to be given to congressional establishment of a sophisticated regulatory scheme in addressing questions of legislative intent and purpose. The 1974 decision in National Railroad Passenger Corp. v. National Association of Railroad Passengers (Amtrak) ${ }^{40}$ effectively embodied a presumption against the existence of a private right of action for every party injured by a statute's breach where the statute explicitly provides such a right for some injured parties. Amtrak was a suit by a group of passengers who claimed that the Amtrak Act ${ }^{41}$ created a private right to sue to enjoin Amtrak from canceling certain train routes. The Court resurrected the maxim expressio unius est exclusio alterius ${ }^{42}$ to support its conclusion that because the Act expressly conferred a right to sue on the Attorney General of the United States and in some cases on employees, it could safely be assumed that Congress did not intend to create such a right in other private parties. ${ }^{43}$

never since made explicit use of this "test," and the reaction of the lower federal courts was decidedly mixed. See Note, Implied Private Actions Under Federal Statutes-The Emergence of a Conservative Doctrine, 18 WM. \& MARY L. Rev. 429, 433-35 \& nn.25-27 (1976) (citing cases).

38. Wheeldin v. Wheeler, 373 U.S. $647,650-52$ (1963).

39. Calhoon v. Harvey, 379 U.S. 134, 138-41 (1964). Cf. International Ass'n of Machinists v. Central Airlines, Inc., 372 U.S. 682, 689-90 (1963) (Congress must have intended statutory rights to be judicially enforceable "[i]n view of the clearly stated purposes of the [Railway Labor] Act and of its history").

40. 414 U.S. 453 (1974).

41. Rail Passenger Service Act of 1970, as amended, 45 U.S.C. $\S \S 501-644$ (1970).

42. "The expression of one thing is the exclusion of another."

43. 414 U.S. at 458. In support of this maxim, the Court cited Botany Worsted Mills v. United States, 278 U.S. 282, 289 (1929) (where Congress has created one remedy, courts should not imply another). Fourteen years after deciding Botany Mills, however, the Court had asserted that the expressio unius maxim should be applied with caution to modern statutes. SEC v. C.M. Joiner Leasing Corp., 320 U.S. 344, 350-51 (1943) (ancient maxims of statutory construction often originated in sources "hostile" to legislative action and must sometimes be "subordinated" to general legislative purpose and policy). The Amtrak Court conceded that expressio unius would yield to clear evidence of a contrary legislative intent, 414 U.S. at 458, but that was a narrower exception than those mentioned in Joiner. Even so, the maxim is not without its modern-day adherents. See, e.g., 2A C. Sands, SUTherland's Statutes and Statutory Construction $\$ 57.10$, at 428-29 (4th ed. 1973) (citing cases). For some critics of the use of expressio unius in Amtrak, see, e.g., McMiahon \& Rodos, supra note 15, at 84; Comment, supra note 7, at 
The following term, in Securities Investor Protection Corp. v. Barbour, ${ }^{44}$ the Court qualified its Amtrak holding. Although the Court called the statutory construction problems in the two cases analogous, it did not cite Amtrak's expressio unius reasoning. ${ }^{45}$ Central to $\mathrm{Am}$ trak, said the Court, was the proposition that " 'the inference of such a private cause of action not otherwise authorized by statute must be consistent with the evident legislative intent and, of course, with the effectuation of the purposes intended to be served by the Act." "46

By the 1970s, just prior to Cort, the number of criteria facing the plaintiff claiming a private right of action had grown from one, Rigsby's "especial benefit," to three. ${ }^{47}$ In attempting to summarize the criteria in Cort v. Ash, the Court added a fourth question: "[i] s the cause of action one traditionally relegated to state law?" $\$$ s Although earlier cases had frequently referred to state law as providing the plaintiff's cause of action, ${ }^{49}$ Cort cited no case that explicitly found that criterion relevant to implying a cause of action based on federal law. ${ }^{50}$

The Court left unanswered the questions whether a plaintiff was required to meet all four criteria before a private right would be implied and, if not, which criteria carried greater weight. ${ }^{51}$ The precedents make clear, however, that at the very least failure to meet

1417; Note, The Phenomenon of Implied Private Actions Under Federal Statutes: Judicial Insight, Legislative Oversight or Legislation by the Judiciary?, 43 FoRDHAM L. REV. 441, 445,457 (1974).

44. 421 U.S. 412 (1975). Barbour held that a broker-dealer's customers do not have an implied right of action under the Securities Investor Protection Act of 1970, 15 U.S.C. $\$ \$ 78 \mathrm{aaa}-78111$ (1970), to compel the Securities Investor Protection Corporation to act on their behalf.

45. 421 U.S. at $418-21$.

46. Id. at 418 (citing 414 U.S. at 457-58). The Court has not mentioned the expressio unius maxim in any of the implication cases decided since Amtrak. Combined with Barbour's language, this may well indicate a judicial retreat from its use. But cf. Note, supra note 15, at 383 (Cort approach "even more restrictive" than Amtrak approach).

47. The three criteria are the questions of "especial benefit," legislative intent, and legislative purpose. For an argument that a plaintiff is required to meet all three, sce p. 1387 infra.

48. Cort v. Ash, 422 U.S. 66, 78 (1975).

49. E.g., Wheeldin v. Wheeler, 373 U.S. 647, 652 (1963); see Montana-Dakota Utils. Co. v. Northwestern Pub. Serv. Co., 341 U.S. 246, 250 (1951).

50. 422 U.S. at 78. But cf. Paul v. Davis, 424 U.S. 693, 697-99 (1976) (suggesting that existence of state remedy is relevant to whether action is permissible under 42 U.S.C. $\$ 1983$ (1970)); Tipton v. Atchison, T. \& S.F. Ry. Co., 298 U.S. 141, 147-48 (1936) (where state provides workmen's compensation as substitute for common law action, common law remedy for breach of federal safety statutes need no longer be implied).

51. See Peterson, Implied Remedies Under Federal Statutes: A New Look, 80 Com. L.J. 480,483 (1975) (Court did not indicate whether all four criteria must be met); 47 MISs. L.J. 156, 163 (1976) (degree of test's restrictiveness unclear until lower court rulings because Court did not indicate whether plaintiff had to satisfy all four criteria). 
the "especial benefit" criterion would defeat the private right. ${ }^{52}$ Logically, evidence of a legislative intent contrary to permitting private suits would also be decisive, and the Court said as much in Cort. ${ }^{53}$ Although the precedents do not fully suggest the weight to be given to the "underlying purposes" criterion, ${ }^{54}$ that test held considerable sway in Cort. Justice Brennan's opinion for the Court permitted that criterion to affect the judgments concerning both the "especial benefit" criterion and the "state law" criterion..$^{55}$ The Court has since implied that a finding that a remedy exists under state law should not be decisive. ${ }^{50}$ Thus it appears that the first three criteria constitute a test for implication, with the fourth criterion relevant if the others yield an uncertain result. It further appears that the "underlying purposes" criterion can have an important impact on the way in which the others are viewed.

\section{B. Civil Rights: A Generous Approach to Implication}

Regardless of whether the test for implication promulgated in Cort v. Ash is viewed as restrictive, a similar analysis had never been applied prior to Cort in cases in which the plaintiff sought to protect his or her civil rights. When a plaintiff has claimed an implied right of action under a federal statute in order to remedy forbidden discrimination, the Court has been noticeably sympathetic to the

52. See note 35 supra (discussing cases). Meeting the especial benefit criterion, on the other hand, is not sufficient in itself. See Securities Investor Protection Corp. v. Barbour, 421 U.S. 412,421 (1975) (although statute enacted for benefit of plaintiff's class, private right still not implied).

53. Cort v. Ash, 422 U.S. 66, 82 (1975). See Peterson, supra note 51, at 482 (explicit legislative intent not to permit private actions is controlling). Cf. National R.R. Passenger Corp. v. National Ass'n of R.R. Passengers, 414 U.S. 453, 458 (19'74) ("even the most basic general principles of statutory construction must yield to clear contrary evidence of legislative intent").

54. Although the precedents appear to indicate that inconsistency might be sufficient to deny a private right, they do not make clear what degree of consistency would be enough to confer one. See Securities Investor Protection Corp. v. Barbour, 421 U.S. 412, 421 (1975) (private right of action not "necessary to or . . . capable of furthering that [congressional] purpose"); National R.R. Passenger Corp. v. National Ass'n of R.R. Passengers, 414 U.S. 453, 461 (1974) (denial of private right "completely consistent with the Act as a whole"); T.I.M.E. Inc. v. United States, 359 U.S. 464, 474 (1959) (private right "incompatible with ... statutory scheme").

55. The Court undertook a purpose inquiry as part of its answer sto the "especial benefit" question and determined that the protection of the plaintiff's class was at best a "subsidiary purpose" of the statute. Cort v. Ash, 422 U.S. 66, 80-81 (1975). In determining whether a traditional state remedy had been displaced, the court concluded that relegating the plaintiff to state law would not hinder the congressional "goal." Id. at 85.

56. See Santa Fe Indus., Inc. v. Green, 430 U.S. 462, 478 (1977) (existence of state law remedy "not dispositive" of implication question). 
claim. Its reasoning in the civil rights cases has been similar to that in the major strand, but the criteria have been applied in a broad, not a restrictive, manner. ${ }^{57}$

The cases finding private rights of action under civil rights statutes are not numerous, but they nevertheless indicate a consistently favorable attitude toward permitting suits under such statutes. The first cases to imply private causes of action to protect civil rights were the Court's 1944 decisions in Steele v. Louisville \& Nashville Railroad $^{58}$ and Tunstall v. Brotherhood of Locomotive Firemen and Enginemen. ${ }^{59}$ Those decisions held that black employees possessed an implied right of action to sue under the Railway Labor Act to remedy harm caused by discriminatory agreements entered into by management and a union. ${ }^{60}$ The Court used a two-step analysis to find the right. First, the Court found that the union had a statutory duty of fair representation that included an implicit duty not to discriminate on the basis of race: "Congress plainly did not undertake to authorize the bargaining representative to make such discriminations." ${ }^{1}$ Second, the Court reasoned that if private suits were not permitted the workers' right to be immune from discrimination by their representatives "would be sacrificed or obliterated." 62

Although nearly a quarter of a century passed before the Supreme Court confronted another case involving implication of a private right of action to protect civil rights, ${ }^{63}$ at least one court of appeals relied

57. The Court has also provided implied rights of action to protect civil liberties, see Bivens v. Six Unknown Named Agents of the Fed. Bureau of Narcotics, 403 U.S. 388 (1971), and to challenge state welfare enactments, see, e.g., Rosado v. Wyman, 397 U.S. 397 (1970). Both of these areas involve the protection of personal rights granted by federal statute or the Constitution, as do the civil rights cases, and the reading of Cort suggested in this Note might profitably be applied in those areas as well.

58. 323 U.S. 192 (1944).

59. 323 U.S. 210 (1944).

60. Steele v. Louisville \& N.R.R., 323 U.S. 192, 207 (1944); Tunstall v. Brotherhood of Locomotive Firemen \& Enginemen, 323 U.S. 210, 213-14 (1944).

61. Steele v. Louisville \& N.R.R., 323 U.S. 192, 203 (1944). The Steele case is usually cited as the origin of the doctrine of a "duty of fair representation." See, e.g., C. Summers \& H. Wellington, Cases and Materials on Labor LaW 38-46 (1968); Wellington, Union Democracy and Fair Representation: Federal Responsibility in a Federal System, 67 YALE L.J. 1327, 1334-39 (1958).

62. 323 U.S. at 207.

63. The next civil rights case that raised the question of implication was Allen $v$. State Bd. of Elections, 393 U.S. 544 (1969). In the interim, the Court decided in 1948 to permit a private action under 42 U.S.C. $\$ 1982$ (1970), which proscribes certain types of discrimination but provides no explicit remedies. The Court allowed the suit in an action to forbid enforcement of racially restrictive covenants by the courts in the District of Columbia. Hurd v. Hodge, 334 U.S. 24, 30-36 (1948). Shortly before deciding Allen, the Court extended the $\$ 1982$ remedy to reach purely private housing discrimination as well. Jones v. Alfred H. Mayer Co., 392 U.S. 409 (1968) (injunctive relief granted); $c f$. 
in the interim on the Court's Steele and Tunstall reasoning to find an implied right. The Second Circuit in Fitzgerald v. Pan American World Airways ${ }^{i \pm}$ held that the provisions of the Civil Aeronautics Act forbidding discrimination ${ }^{65}$ granted to black passengers forced to leave a plane due to their race an implied right to sue for damages. ${ }^{66}$ The Second Circuit explicitly noted in Pan American, as had the Supreme Court in both Steele and Tunstall, that the statutory remedy was not sufficient to protect the rights granted to the plaintiffs. ${ }^{67}$ The problem in Steele and Tunstall was the employees' inability to trigger the statutory remedy; in Pan American, the Civil Aeronautics Board was incapable of making the plaintiffs whole. ${ }^{88}$

By the mid-1960s, the Supreme Court was taking a generally restrictive view of implication where an administrative enforcement mechanism existed. ${ }^{69}$ But the Court's 1969 decision in Allen v. State Board of Elections ${ }^{70}$ made clear that this restrictive view would not be extended to civil rights cases. In Allen the Court held that individual voters had an implied right to challenge local voting enactments under section five of the Voting Rights Act of $1965,{ }^{11}$ notwithstanding the Act's explicit grant of enforcement authority to the Attorney General of the United States. ${ }^{22}$ The Court concluded that a private right of action should be implied because the Attorney General's limited resources made the explicit statutory remedy inadequate: "The achievement of the Act's laudable goal could be severely hampered ... if each citizen were required to depend solely on litigation instituted at the discretion of the Attorney General."'73

Sullivan v. Little Hunting Park, Inc., 396 U.S. 229 (1969) (damages also available). The Court declined at least one opportunity to hear another case involving implication to enforce civil rights when, in 1964, it denied certiorari to review a Fifth Circuit holding that the United States had no implied right to sue local boards of education for segregating children of local military personnel. United States v. Madison County Bd. of Educ., 326 F.2d 237 (5th Cir.), cert. denied, 379 U.S. 929 (1964). The Madison County decision was a refusal to imply a public, not a private, right of action and is thus not inconsistent with a broad right to sue for individuals who have been subject to discrimination.

64. 229 F.2d 499 (2d Cir. 1956).

65. Civil Aeronautics Act of 1938, $\$ \S 404(b), 902(a), 1106,49$ U.S.C. $\$ \S 484(b), 622(a)$, $676(1940)$ (current version at 49 U.S.C. $\$ 1374(b)(1970)$ ).

66. 229 F.2d at 501-02.

67. Id. at 502 .

68. Id.

69. See pp. $1383-86$ supra.

70. 393 U.S. 544 (1969).

71. 42 U.S.C. $\S 1973 c$ (1970).

72. Id.; see 393 U.S, at 554-57. See generally Roman, Section 5 of the Voting Rights Act: The Formation of an Extraordinary Federal Remedy, 22 AM. U.L. REv. 111, 116-17 (1972).

73. 393 U.S. at 556 (footnote omitted). 
Allen clarifies the distinction between the dominant strand and the civil rights cases: whereas in Borak the private right of action was implied because it was "necessary," 74 it was enough in Allen that without the private remedy the Act's effectiveness would be "severely hampered." 75 The emphasis in Allen was on extending the broadest possible protections to the plaintiffs' federally protected right to be free from discrimination; without the private right, the Court said, the statute's guarantees "might well prove an empty promise."76

The distinction between the two strands of cases was brought into stark relief in 1974 when, just twelve days after restricting in Amtrak the test for implication in the main strand, the Court decided Lau v. Nichols. ${ }^{77}$ Lau permitted a private suit under Title VI of the Givil Rights Act of $1964^{78}$ to force a school district receiving federal funds to comply with regulations prohibiting recipients from discriminating on the basis of race. ${ }^{79}$ The school district argued in its brief that no private right existed, ${ }^{80}$ but the Court did not even discuss the question, despite the fact that Title VI and the regulations promulgated under it expressly provided for an administrative enforcement mechanism. ${ }^{81}$ Instead, the Court simply stated that it was relying on Title $\mathrm{VI}^{82}$ and held for the plaintiffs on the merits. ${ }^{83}$ Although it has been argued that Lau was not in fact a case involving a private right of action, ${ }^{84}$ it has certainly been read as one. ${ }^{8 \mathrm{~J}}$

74. J.I. Case Co. v. Borak, 377 U.S. 426, 433 (1964).

75. Allen v. State Bd. of Elections, 393 U.S. 544, 556 (1969).

76. Id. at 557 .

77. 414 U.S. 563 (1974). Lau was decided on January 21, 1974; Amtrak was decided on January $9,1974$.

78. 42 U.S.C. $\$ 2000 d(1970)$.

79. 414 U.S. at 564-66.

80. Brief for Respondents in Opposition to Petition for Writ of Certiorari, at 7 ("Respondents ... contend that the Fourteenth Amendment and the Civil Rights Act do not give a party a federal cause of action every time a School District fails to resolve a problem-not of its own making-presented to it by a student." (emphasis added)).

81. See 42 U.S.C. $\$ 2000 \mathrm{~d}-1$ (1970).

82. 414 U.S. at 566. The plaintiffs also claimed violations of the equal protection clause. $I d$. at 565 . The cause of action was founded at least in part on 42 U.S.C. $\$ 1983$ (1970). Plaintiffs' Complaint for Injunction and Declaratory Relief at 4, Lau v. Nichols, 414 U.S. 563 (1974). See Cannon v. University of Chicago, 559 F.2d 1077, 1083 n.7 (7th Cir. 1977), petition for cert. filed, 46 U.S.L.W. 3438 (U.S. Dec. 28, 1977) (No. 77-926).

83. 414 U.S. at 566-69.

84. Cannon v. University of Chicago, 559 F.2d 1077, 1083 (7th Cir. 1977), petition for cert. filed, 46 U.S.L.W. 3438 (U.S. Dcc. 28, 1977) (No. 77-926), discussed at pp. 1393-96, 1400-07 infra.

85. See, e.g., Lloyd v. Regional Transp. Auth., 548 F.2d 1277, 1280 (7th Cir. 1977); Serna v. Portales Mun. Schools, 499 F.2d 1147, 1152-53 (10th Cir. 1974); Barnes v. Converse College, 436 F. Supp. 635, 638 (D.S.C. 1977); Shelton \& Berndt, supra note 3, at 1157. Even before Lau, numerous lower courts had permitted private rights of action 
Thus it is clear that in civil rights cases, in contrast with most other types, the mere existence of an administrative enforcement mechanism does not bar implication of private rights of action. ${ }^{86} \mathrm{Un}$ der the Cort test, such a mechanism may be evidence of an intent to exclude a private right, as well as of inconsistency of a private right with the statute's purpose. ${ }^{87}$ But in civil rights cases, the Court has paused to test the adequacy of the enforcement mechanisms in protecting the plaintiffs' civil rights against the statute's broad underlying purpose of protecting those rights. Furthermore, because many of the cases in the two strands are essentially contemporaneous, the differences in their approach cannot be explained simply in terms of the Court's changing philosophy; 88 the distinction seems instead to revolve around the nature of the rights involved. As one commen-

to enforce the guarantees of Title VI against private parties. See, e.g., Bossier Parish School Bd. v. Lemon, 370 F.2d 847, 852 (5th Cir.), cert. denied, 388 U.S. 911 (1967). See note 148 infra (legislative history of Section 504 supports notion of private right of action under Title VI and Title IX).

86. Another area in which the existence of an administrative review mechanism does not bar private suits is in welfare law. The broad approach to implication under civil rights statutes identified in this Note is in fact little different from the broad approach the Supreme Court has taken to various administrative law doctrines in cases involving welfare recipients seeking to challenge state welfare regulations as inconsistent with federal law and thus as violative of their federal rights. In such cases the Court has permitted the plaintiffs to circumvent virtually the entire panoply of doctrines that usually insulates administrative regulation from interference through private suits. See Rosado v. Wyman, 397 U.S. 397, 405-06 (1970). The Court said that the administrative review mechanisms available to welfare recipients are inadequate primarily because the recipient cannot trigger review of the state regulatory scheme. Id. at $406 \mathrm{n} .8$. See Herzer, Federal Jurisdiction Over Stalutorily-Based Welfare Claims, 6 HARv. C.R.-C.L.L. REv. 1, 9-12 (1970) (discussing policy); Note, Federal Judicial Review of State Welfare Practices, 67 Colum. L. REv. 84, 91-92, 102 (1967) (discussing inadequacy of HEW's administrative review mechanisms).

The administrative law doctrine of "primary jurisdiction," waived in Rosado, developed for much the same purpose as did the restrictive view of implication under statutes providing for administrative enforcement: protection of the integrity and uniformity of the regulatory schemes set up by Congress by deferring to the judgment of the regulators selected by Congress. See generally $3 \mathrm{~K}$. Davis, Administrative Law Treatise $\$ 19.02$, at 7 (1958). The Court made exceptions for welfare recipients because they asserted personal federal rights that the available administrative remedy could not protect. 397 U.S. at 406. Logically, the Court should take a similarly broad view of implication for plaintiffs in civil rights cases, who assert similar rights and face an even greater barrier, given the administrative discretion embodied in many enforcement schemes.

87. This was the holding of Amtrak, the case cited in Cort for the "intent" criterion. See pp. 1385-86.

88. See, e.g., Deutsch \& LaRue, Federalism and the Law of Securities Regulation: The Legacy of Brown v. Board of Education, 34 W WSH. \& LEE L. REv. 799, 807-08 (1977) (suggesting private right found in Borak would survive under strict application of Cort $v$. Ash analysis). If this is true, then Borak is not easily written off as a product of the Warren Court's liberalism, nor Cort $v$. Ash as a product of the Burger Court's conservatism. But see McMahon \& Rodos, supra note 15, at 167-68, 190-92 (restrictive view of implication is due to Burger Court's conservatism). 
tator has put it, the "implied remedy path into federal court is a narrow one, but if there is any lesson to be learned from the Supreme Court's racial discrimination decisions of the past two decades, it is that the Court will give the broadest sweep possible to congressional statutes aimed at racial equality." 80

\section{Civil Rights Law after Cort v. Ash}

The Supreme Court's attempt in Cort $v$. Ash to restate the law of implication failed to indicate any explicit limitations on the types of cases within the doctrine's scope. Perhaps as a result, many lower federal courts have applied the Cort criteria as a restrictive test for implication even in suits claiming private rights of action to redress forbidden discrimination.90 This approach is misguided. There are important reasons of policy and tradition not to let the potential restrictiveness of the criteria applicable to the major line of cases undercut the broad scope of the implication doctrine that has prevailed until now in civil rights cases.

\section{A. Cort v. Ash and Civil Rights in the Lower Courts}

Since Cort v. Ash lower courts faced with the question whether to imply a private right of action under a statute not expressly providing one have generally applied that opinion's "relevant" criteria as a four-pronged test. They have permitted a private right of action only where a plaintiff has demonstrated that all four criteria either are neutral or favor implication. ${ }^{91}$ Several courts have even read $\mathrm{Am}$ -

89. Karst, Federal Remedies, 54 U. Der. J. URB. L., 1025, 1030 (1977). It appears that Karst and Shelton \& Berndt, supra note 3, are the only commentators to suggest that civil rights statutes should be treated any differently from others in the implication equation. Professor Karst made only the broad statement quoted, without elaboration; Shelton \& Berndt did not make this suggestion explicitly, but it follows from their contention that there are "weighty policies favoring implication" where the statute's "dominant purpose" is to forbid discrimination. Shelton \& Berndt, supra note 3, at 1158.

90. Compare Cannon v. University of Chicago, 559 F.2d 1063 (7th Cir. 1976), aff'd on rehearing, 559 F.2d 1077 (7th Cir. 1977), petition for cert. filed, 46 U.S.L.W. 3438 (U.S. Dec. 28, 1977) (No. 77-926) (private right under Title IX denied); People's Hous. Dev. Corp. v. City of Poughkeepsie, 425 F. Supp. 482, 490-94 (S.D.N.Y. 1976) (private right under Housing and Community Development Act of 1974 denied) and Cape v. Tennessee Secondary School Athletic Ass'n, 424 F. Supp. 732, 738 (E.D. Tenn. 1976), rev'd on other grounds, 563 F.2d 793 (6th Cir. 1977) (private right under Title IX denied) with Lloyd v. Regional Transp. Auth., 548 F.2d 1277, 1285-86 (7th Cir. 1977) (private right under Section 504 implied); NAACP v. Wilmington Medical Center, Inc., 426 F. Supp. 919, 924-25 (D. Del. 1977) (private right under Section 504 implied) and Silva v. East Providence Hous. Auth., 423 F. Supp. 453, 465 (D.R.I. 1976) (private right under Low-Rent Housing Act implied).

91. See note 90 supra (citing cases denying private rights); pp. 1386-87 supra (discussing Cort as test). Since its opinion in Cort, the Supreme Court has treated the criteria as a 
trak's expressio unius reasoning into Cort, and this has resulted in denials of private rights of action to combat racial discrimination in housing, ${ }^{92}$ sex discrimination in high school athletics, ${ }^{93}$ and sex discrimination in professional school admissions..$^{94}$

Probably the most important decision to date is the Seventh Circuit's holding in Cannon v. University of Chicago. ${ }^{95}$ Cannon involved a suit by a female applicant who, having been denied admission to a private medical school, claimed that the denial was due to her sex ${ }^{96}$ The major claim for relief ${ }^{97}$ was under Title IX of the Education Amendments of 1972, which forbids discrimination on the basis of sex in most educational programs receiving federal funds. ${ }^{98}$

The plaintiff contended that Title IX creates a private right of action. But the Seventh Circuit, citing Cort $v$. Ash, held that no such private right of action had been conferred. ${ }^{99}$ The Cannon litigation was before the court of appeals twice. ${ }^{100}$ The first time the panel read the Supreme Court's opinions in Amtrak (including the expressio unius maxim), Barbour, and Cort together as creating a presumption against a private right of action. ${ }^{101}$ The Seventh Circuit distinguished Lau on the grounds that, although Title IX's language and enforcement

"test"-although perhaps not the only test-for implying a private right of action. Twice, it has discussed the Cort factors in denying a private right. See Santa Fe Indus., Inc. v. Green, 430 U.S. 462, 477.79 (1977); Piper v. Chris-Craft Indus., Inc., 430 U.S. 1, $37-41$ (1977).

92. People's Hous. Dev. Corp. v. City of Poughkeepsie, 425 F. Supp. 482, 493-94 (S.D.N.Y. 1976). But cf. Silva v. East Providence Hous. Auth., 423 F. Supp. 453, 464-66 (D.R.I. 1976) (even where provision for administrative enforcement exists, private right implied for potential low-income tenants to challenge decision not to construct previously planned housing project).

93. Cape v. Tennessee Secondary School Athletic Ass'n, 424 F. Supp. 732 (E.D. Tenn. 1976), rev'd on other grounds, 563 F.2d 793 (6th Cir. 1977) (implied right under Title IX denied). But cf. Berkelman v. San Francisco Unified School Dist., 50I F.2d 1264 (9th Cir. 1974) (question of implied right of action not reached because discrimination on basis of sex violated Fourteenth Amendment).

94. Cannon v. University of Chicago, 559 F.2d 1063 (7th Cir. 1976), aff'd on rehearing, 559 F.2d 1077 (7th Cir. 1977), petition'for cert. filed, 46 U.S.L.W. 3438 (U.S. Dec. 28, 1977) (No. 77-926).

95. Id.

96. Id. at 1067 .

97. Id. at 1071-72.

98. 20 U.S.C. $\$ \S 1681-1686$ (Supp. V 1975). The statute states, in pertinent part: "No person in the United States shall, on the basis of sex, be excluded from participation in, be denied the benefits of, or be subjected to discrimination under any education program or activity receiving Federal financial assistance." Id. $\$ 1681$ (a). See also note 148 infra (legislative history).

99. 559 F.2d at 1073-74.

100. See id. at 1077 .

101. Id. at 1074: "The teaching of Amtrak, [Barbour] and Cort ... is that a private cause of action should not be lightiy implied under a statute where Congress has not specifically provided one ...." 
provisions are completely analogous to those of Title VI, Lau was a class action on behalf of a large number of students, whereas in Cannon there was only a single plaintiff. ${ }^{102}$

After the first Cannon decision the panel, expressing concern that Lau $v$. Nichols might have been misconstrued in its initial opinion, ${ }^{103}$ granted a petition for rehearing. ${ }^{104}$ The panel also considered on rehearing whether the Attorney's Fees Act, ${ }^{105}$ which granted federal courts power to award attorney's fees in actions to enforce Title IX, indicated a congressional intent to create a private right of action under Title IX.106 The panel rejected the Attorney's Fees Act claim. ${ }^{107}$ It then proceeded to discuss Cort in greater detail, but again the court ultimately was persuaded by its earlier reading of Amtrak: Congress had provided for enforcement through administrative review by the Department of Health, Education and Welfare, and the federal courts should not imply another. ${ }^{108}$ The panel went on to attempt to distinguish Lau $v$. Nichols on the ground that the cause of action in that case was in fact provided by section $1983,{ }^{100}$ and not by Title VI directly. ${ }^{110}$ The Cannon opinion thus placed the Amtrak stumbling

102. Id. at 1072 (citing Lau v. Nichols, 414 U.S. 563, 571-72 (1974) (Blackmun, J., concurring)). See Serna v. Portales Mun. Schools, 499 F.2d 1147, 1153-54 (10th Cir. 1974) (key to Lau was number of students involved). In other words, so the argument runs, plaintiffs who are only part of a larger class of discriminatees have a claim that a court will enforce, but a plaintiff who is an individual has no such claim. That seems a particularly unlikely result for Congress to have intended or even considered.

103. 559 F.2d at 1077 .

104. Id. at 1077. After the petition was granted, but before the rehearing, a second panel in the Seventh Circuit decided in Lloyd v. Regional Transp. Auth., 548 F.2d 1277 ( 7 th Cir. 1977), that a private right of action existed under section 504 of the Rehabilitation Act of 1973, 29 U.S.C. $\$ 794$ (Supp. V 1975), which forbids discrimination on the basis of handicap in federally funded programs, and which has language and enforcement provisions tracking those of both Title VI and Title IX. All three statutes by their terms put their emphasis on the persons whom they protect (Title VI and Title IX protect every "person" from discrimination, and section 504 protects every "otherwise qualified handicapped individual"), and not on the programs receiving funds. The Department of Health, Education and Welfare uses the same enforcement procedures for all three statutes. Sec 45 C.F.R. $\$ \$ 80.6-80.9$ (1976).

Dicta in the Lloyd opinion indicated that panel's doubt about the Cannon result. 548 F.2d at 1287. But although the Cannon panel distinguished Lloyd on rehearing, it did not discuss that case in any detail. 559 F.2d at 1082.

105. Civil Rights Attorney's Fees Award Act of 1976, Pub. L. No. 94-559, $\$ 2,90$ Stat. 2641 (to be codified at 42 U.S.C. $\$ 1988$ ).

106. 559 F.2d at 1077-80.

107. Id. But see note 148 infra (discussing Act's legislative history).

108. 559 F.2d at 1081. The panel also said that it failed to see what good private suits would do. Id. at 1074-75.

109. 42 U.S.C. § 1983 (1970).

110. 559 F.2d at 1081-83 \& nn.6-7. Such an argument asserts that an individual has a private right of action because of $\S 1983$ to enforce Title VI and similar statutes where his or her benefits from the federal government are distributed through public agencies, but that there is no private right of action where the same benefits flow through private 
block of expressio unius in the path of civil rights litigants, even though it is no longer clear that the expressio doctrine applies in any implication cases. ${ }^{111}$

Other cases that have attempted to apply Cort $v$. Ash to civil rights statutes have not gone into as much detail as Cannon. ${ }^{112}$ It remains clear, however, that so long as the Cort analysis is applied restrictively to civil rights statutes, most plaintiffs seeking private rights will continue to be dismissed for failure to state a cause of action. ${ }^{113}$ The

organizations. To make such an argument, it is necessary to infer that Congress, in enacting Title VI and similar statutes, sought to create two classes of beneficiaries of federal funds. The first class of beneficiaries would be able to seek judicial relief for their personal harm, thus satisfying the statutory command that they not be excluded. The second class would only have the right to seek to have the federal government terminate funding to the program that had excluded them. But this second group of beneficiaries could never, absent a private action, be made whole for the personal injury they had suffered. As a result, the statutory guarantee that "[n]o person" should be subjected to discrimination in the program would extend only to some of the beneficiaries, with the key distinction becoming the identity of the defendant in the action. This anomaly was pointed out by a federal magistrate in Alexander v. Yale, C. No. N-77-277, slip op. at 9 (D. Conn. Dec. 21, 1977):

It naturally has been suggested that such Title VI cases have been against "public" defendants and therefore strictly rest on the Civil Rights Act's grant of the right to sue for a deprivation under color of state law "of any rights . . . secured by the Constitution and laws," 42 U.S.C. $\$ 1983$, see Cannon . . . at 1083. If so, it could hardly be a principled distinction that one student would be at Yale and another at the University of Connecticut; if the state college student can secure judicial relief under $\$ 1983$, the more reason to imply a suit right [sic] for the identically situated private university student ....

In other words, the $\S 1983$ distinction may be viewed as an argument in favor of implication. Common sense does not demand the conclusion that Congress intended to grant special protection to private parties wishing to use federal funds to discriminate. See also note 145 infra (implication question may not be so much what legislature did intend as what it would have intended had it considered problem).

One commentator has also suggested that even where $\S 1983$ creates the plaintiff's cause of action, the federal court must still determine whether he has a federal "right" under some other statute. Mowe, Federal Statutes and Implied Private Actions, 55 Ore. L. REv. 3, $7 \mathrm{n.31}$ (1976). This has the flavor of an argument concerning standing, not implication. See note 7 supra.

111. See note 46 supra (suggesting that expressio unius may no longer be law). By its use of expressio units, Cannon raised what amounted to a presumption against a private right of action where Congress had provided any enforcement mechanism. This is a stricter view than that taken in Amtrak, which introduced expressio unius into the jurisprudence of implication. In Amtrak the statute not only created an administrative enforcement mechanism but also a private right of action in some parties. See p. 1385 supra. Thus the test Cannon applied to this civil rights action was more restrictive than the prevailing test in the major strand.

112. See note 90 supra (citing cases). One court did state that it was "in agreement with" the Cannon opinion's holding. Cape v. Tennessee Secondary School Athletic Ass'n, 424 F. Supp. 732, 738 (E.D. Tenn. 1976), rev'd on other grounds, 563 F.2d 793 (6th Cir. 1977). Although the Cape court refused to imply a private right of action under Title IX, it nevertheless found for the plaintiffs on the merits of the alternative cause of action, which was founded on the Fourteenth Amendment. Id. at 742-44.

113. See Wheeldin v. Wheeler, 373 U.S. 647, 649, 652 (1963) (dismissal for failure to state cause of action is proper course where implied right of action is asserted but not permitted). 
Cannon reasoning at the very least would deny private rights of action under Title VI and section 504 of the Rehabilitation Act of $1973,{ }^{114}$ both of which are analogous to Title IX in language and enforcement provisions, and might even deny the private right under the Voting Rights Act found in Allen. ${ }^{115}$

\section{B. Cort v. Ash, Judicial Intent, and Tradition}

Federal courts that have mechanically applied the Cort $v$. Ash criteria restrictively in testing for a private right of action under civil rights statutes have failed either to discern or at least to mention the difference in the way the Supreme Court has treated the two strands of implication cases. ${ }^{116}$ Yet there is no reason to assume-and some reason to doubt-that the Supreme Court intended Cort to operate restrictively on private rights of action for enforcement of civil rights statutes. In briefing the question whether the statute at issue created an implied private right of action, neither party to the Cort litigation cited any cases involving civil rights. ${ }^{117}$ More important, neither the Cort opinion nor the other recent implication cases have discussed the civil rights strand at any length, although Justice Marshall's opinion

114. 29 U.S.C. $\$ 794$ (Supp. V 1975).

115. The statute at issue in Allen provided for administrative enforcement through the Attorney General. See 42 U.S.C. $\$ 1973 c$ (1970). Under the Cannon reasoning, this would seem almost sufficient in itself to bar implication.

116. But see People's Hous. Dev. Corp. v. City of Poughkeepsie, 425 F. Supp. 482, 488-90 (S.D.N.Y. 1976). The People's Housing opinion contended that two strands of implication cases in fact existed, but traced their differences to the court's view of the source of the right. Drawing at least in part on Comment, supra note 7, at 1412, the People's Housing court explained the distinction as follows:

The distinction between these two approaches stems from differing conceptions as to the source of a court's power to create a private right of action . . . . Thus, one line of cases is governed by the belief that the judiciary's power in this area is, for the most part, incidental to that of Congress in enacting the legislation; therefore, no private right of action should be inferred unless there is an indication from the legislative history or from the language of the statute itself that Congress intended such to be the case....

The second line of cases is oriented towards the allowance of individual suits; in these precedents, the courts justified their ability to "legislate" private actions as being inherent in their power, as courts of common law, to fashion appropriate redress for intrusion upon federal rights.

425 F. Supp. at 489 . The court was not identifying the same two strands as this Note; the court cited Amtrak and Barbour as supporting the first strand, and cited Rigsby, Bivens and Borak to support the second strand. Cort was interpreted as an attempt to reconcile the two strands. Id. at 490 .

117. See Brief for Petitioners at 20-74, Cort v. Ash, 422 U.S. 66 (1975). The respondents did cite Allen, but not to contend that there would be a discrepancy between an adverse ruling and the Allen result. Instead, they cited it as the second of three cases in a string cite for a proposition that was not explicitly discussed in Allen, that is, implication of a cause of action is sometimes necessary as a "deterrent." Brief for Respondents at 21, id. 
for the Court in Barbour made clear that Allen was not being overruled. ${ }^{118}$

Allen, Steele, Tunstall, and Lau might all have been decided differently under a strict application of the Cort reasoning; if Allen remains good law, as it apparently does, ${ }^{119}$ this is not so because the logic of Cort inexorably demands it. The statute in Allen provided explicitly for administrative enforcement. There was no finding that a private cause of action was "necessary," only that enforcement would be "severely hampered" without it. Similarly, Congress had created administrative agencies to enforce the statutes at issue in Steele, Tunstall, Pan American, and Lau, but that did not bar the finding of an implied right of action. Under the restrictive view of Cort exemplified by Cannon, no private right would have existed. ${ }^{120}$ Yet Lau v. Nichols was decided by a unanimous Court the term before Cort and just twelve days after Amtrak.

In addition to doubts that may be raised concerning the Court's intention to restrict implication under civil rights statutes as well as under other types, strong policy reasons support a more expansive approach to private rights of action for enforcement of civil rights. In the civil rights area, there is no danger that implication will prove inconsistent with the statute's underlying purposes. A civil rights statute usually has the comprehensive purpose of eliminating some form of discrimination. Thus there is no need for a court to balance the individual rights asserted under the statute against a broader interest that the statute also seeks to protect. The protection of such individual rights is exactly the broader interest the statute seeks to further..$^{121}$

In addition, a court faced with the decision whether to imply a

118. Securities Investor Protection Corp. v. Barbour, 421 U.S. 412, 423-25 (1975).

119. See id.

120. Steele, Tunstall, and Lau all found private rights of action under statutes that included explicit provisions for administrative remedies, see pp. 1388-89 supra; under the restrictive view of the Cort analysis exemplified by Cannon, this alone would be sufficient to deny the private right of action. The plaintiffs in Steele and Tunstall would have at least some difficulty circumventing the very first Cort criterion, which asks whether the plaintiffs are members of the class for whose "especial" benefit the statute was enacted. The Railway Labor Act was enacted to benefit all union members, not merely black ones, and the provisions that create the duty of fair representation do not say anything explicit about racial discrimination. See Railway Labor Act, $\S 2$, as amended, 45 U.S.C. $\$ \$ 151 \mathrm{a}-152$ (1970).

121. For example, in the area of cconomic regulation, even if the statute was enacted for the plaintiff's "especial benefit," a private suit could still interfere with uniform regulation that Congress intended and hence be inconsistent with the underlying purposes. See, e.g., Securities Investor Protection Corp. v. Barbour, 421 U.S. 412, 421 (1975). In the civil rights area, the underlying purpose is only to extend the fullest possible protection to the rights of the plaintiff. See pp. 1401-06 infra. 
private right under a civil rights statute will rarely need to puzzle, as did the Supreme Court in Cort v. Ash, over the litigant's status as a "primary" or "secondary" beneficiary of the statute.122 Most civil rights statutes make clear by their terms the class or classes that they seek to protect from discrimination, ${ }^{123}$ and whether the class is defined along racial, ethnic, religious, or sexual lines, the plaintiff's membership in it usually is easily discerned.124

Even when an administrative enforcement mechanism exists under a civil rights statute, its relation to the statutorily created rights is less pervasive than in the area of regulatory statutes. Under economic regulatory legislation, the rights of the statute's beneficiaries may be intended to be dependent on administrative discretion, ${ }^{125}$ but civil rights are not limited by such discretion. ${ }^{126}$ For example, in the Mon-

122. In Cort the importance of whether the rights sought to be vindicated were the "primary" or "secondary" object of the statute was emphasized. 422 U.S. at 80-85. Accord, Santa Fe Indus. v. Green, 430 U.S. 462,478 (1977).

123. It may be argued that this statement demands something of a leap of faith. Statutes such as Title VI and Title IX, which tie their protections against discrimination to the receipt of federal funds by the putative discriminator, might be read as being intended only to save federal funds from taint. See, e.g., Shelton \& Berndt, supra note 3, at 1154 n.200. At least as regards Title VI (which was the model for Title IX), the question has been persuasively answered by the Justice Department:

Section 60I [Title VI] creates personal rights. It provides that "[n]o person in the United States shall, on the ground of race, * * * be excluded" from participation in any federally-assisted program. The rights created by Section 601 run in favor of every person. Congress could as easily have provided that: "No program discriminating on account of race shall receive federal funds." If it had expressed the prohibition in that way, there would be a strong argument that [individuals] . . . could not bring suit. But the statute actually enacted was far broader; it instructs recipients of federal money not to discriminate. It was designed to end discrimination, not simply to allocate federal money to programs that did not discriminate.

Supplemental Brief for the United States as Amicus Curiae at 28-29, Regents of the Univ. of Cal. v. Bakke, No. 76-811 (U.S. 1977) (footnotes omitted). In short, the statutory language of the "spending-power" civil rights statutes indicates by its cmphasis the congressional intent to confer rights on individuals. This conclusion is buttressed, in the case of Title IX, by the legislative history discussed in notes 140 \& 148 infra.

124. Membership in the protected group is more difficult to discern when a plaintiff asserts that he is a victim of what some commentators have called "reverse discrimination" -that is, that remedial programs designed to assist victims of discrimination in turn violate his statutory or constitutional rights to be free of discrimination. In a case before the Supreme Court this term challenging the validity of a public university's affirmative action program in admissions, Regents of Univ. of Cal. v. Bakke, 18 Cal. 3d 34, 553 P.2d 1152, 132 Cal. Rptr. 680 (1976), cert. granted, 429 U.S. 1090 (1977) (No. 76-811), the Court requested both parties to the case to file briefs discussing Title VI as it applies to the case, $98 \mathrm{~S}$. Ct. 293 (1977), and granted permission for the Solicitor General of the United States to do so, id. at 500. Thus the Court may be preparing to decide whether a private right of action exists under Title VI in this situation. $C f$. Flanagan v. President \& Directors of Georgetown College, 417 F. Supp. 377, 378 (D.D.C. 1976) (permitting, without discussing jurisdictional issues, private suit under Title VI to challenge private college's practice of granting preference to members of minority groups in awarding financial aid).

125. See, e.g., note 35 supra (discussing cases).

126. See Allen v. State Bd. of Elections, 393 U.S. 544, 556 \& n.21 (1969) (Attorney General's discretion in enforcement suggests need for private rights). 
tana-Dakota and T.I.M.E. Inc. cases a party claimed a statutory "right" to a certain rate for utility services, but the Court replied that the only "right" was to the rate fixed by the appropriate federal regulatory commission. ${ }^{127}$ By way of contrast, the plaintiffs in Allen were guaranteed the right to be free from all voting enactments diminishing minority voting strength, not only from those the Attorney General chose to challenge. ${ }^{128}$

In addition, civil rights statutes may be enacted to protect constitutional rights. ${ }^{120}$ The Court made clear in Bivens $v$. Six Unknown Named Agents of the Federal Bureau of Narcotics ${ }^{130}$ that private rights of action to protect individual rights secured under the Constitution are favored. ${ }^{131}$ Thus to the extent that suits under some civil rights statutes are in fact efforts to enforce constitutional rights, the second Cort criterion, a limited search for legislative intent, is less important; the provisions of the Constitution, unlike those of a statute, were intended to change meaning with changing times. ${ }^{132}$

Finally, private litigation in federal court has long been recognized as an important tool for the furtherance of the goal of equality. As Judge Friendly has noted, "[i]t is hard to conceive a task more appropriate for federal courts than to protect civil rights." 133 Historically, it has been not the Congress or the executive but the Supreme Court acting at the behest of private litigants that has struck down official and private segregation of many sorts. ${ }^{134}$ The Court recognized

127. T.I.M.E. Inc. v. United States, 359 U.S. 464, 468 (1959); Montana-Dakota Utils. Co, v. Northwestern Pub. Serv. Co., 341 U.S. 246, 250-53 (1951).

128. Allen v. State Bd. of Elections, 393 U.S. 544, 556 n.21 (1969). But cf. Beer v. United States, 425 U.S. 130, 141 (1976) (implying that some voting enactments may violate Constitution but not violate Voting Rights Act; only those that reduce minority voting strength clearly violate $\mathrm{Act}$ ).

129. Although this argument is fairly clear in the case of statutes combatting racial discrimination, such as Title VI and the Voting Rights Act, it is more difficult-although not impossible-to argue that either Title IX, attacking sex discrimination in education, or Section 504, prohibiting discrimination on the basis of handicap, was enacted to protect constitutional rights. But see Comment, Plessy Revived: The Separate But Equal Doctrine and Sex-Segregated Education, 12 HARv. C.R.-C.L.L. REv. 585 (1977) (arguing that sex discrimination in education violates Fourteenth Amendment).

130. 403 U.S. 388 (1971).

131. Id. at 391-97.

132. Constitutional interpretation is a completely different process from ordinary statutory construction. Traditionally, a judge interpreting the Constitution will bear in mind that its meaning was intended to change with the times, in contradistinction to the meaning of a statute. See Missouri v. Holland, 252 U.S. 416, 433 (1920) (Holmes, J.).

133. H. Friendly, Federal Jurisdiction: A General View 90 (1973).

134. Johnson v. Virginia, 373 U.S. 61 (1963) (per curiam) (desegregating courtrooms); New Orleans City Park Improvement Ass'n v. Detiege, 358 U.S. 54 (1958), aff's per curiam 252 F.2d 122 (5th Cir. 1958) (desegregating public parks); Gayle v. Browder, 352 U.S. 903 (1956), aff'g per curiam 142 F. Supp. 707 (M.D. Ala. 1956) (three-judge court) (desegregating public transportation); Holmes v. City of Atlanta, 350 U.S. 879 (1955), vacating per curiam 
well over a decade ago that in the civil rights context "litigation is not a technique of resolving private differences; it is a means for achieving the lawful objectives of equality of treatment by all government, federal, state and local." 135

To the extent that implication involves a search for congressional intent, it seems unlikely that a Congress involved in enacting legislation for the preservation of civil rights would seek to strip the courts of the paramount role they have traditionally played in preserving those rights. ${ }^{136}$ More likely, the administrative enforcement processes are intended to supplement the judicial enforcement that has long characterized the civil rights area.

\section{Cort Properly Applied: The Example of Title IX}

The criteria for finding a private right of action set forth in Cort v. Ash, standing alone, do not seem anything other than neutral. ${ }^{137}$ It is only the manner in which the Court has used the criteria that may properly be labeled restrictive. Properly qualified to reflect the broad purpose underlying civil rights statutes, the Cort criteria can be applied to preserve the favorable view of implication that traditionally has characterized this field. A reexamination of Cannon will serve to illustrate how Cort should be applied to civil rights cases.

The first inquiry pursued in Cort was whether the plaintiff was "one of the class for whose especial benefit the statute was enacted," that is, whether "the statute create[s] a federal right in favor of the

223 F.2d 93 (5th Cir. 1955) (desegregating public golf courses); Mayor of Baltimore v. Dawson, 350 U.S. 877 (1955), aff'g per curiam 220 F.2d 386 (4th Cir. 1955) (desegregating beaches); Brown v. Board of Educ., 347 U.S. 483 (1954) (desegregating public education); Shelly v. Kraemer, 334 U.S. 1 (1948) (outlawing restrictive covenants); Strauder v. West Virginia, 100 U.S. 303 (1880) (invalidating statute that excluded blacks from jury service).

135. NAACP v. Button, 371 U.S. 415, 429 (1963). Accord, S. Goldman \& T. Jahnige, The Federal Courts as a Political System 212 (1971); Kinoy, The Constitutional Right of Negro Freedom Revisited: Some First Thoughts On Jones v. Alfred H. Mayer Company, 22 Rutgers L. REv. 537, 549-52 (1968).

136. Congress may, however, intend administrative remedies to relieve courts of part of their burden of being the sole enforcer of civil rights, and to relieve those who have been subjected to discrimination of the financial burdens often accompanying litigation. See Note, 49 TEMP. L.Q. 207, 213 n.70 (1975) (quoting Sen. Bayh). Nevertheless this would leave the two types of remedies-judicial and administrative-to supplement, not to supplant, one another. See Karst, supra note 89, at 1062.

137. The criteria may be viewed as restrictive rather than neutral if they are seen as four (or possibly three, see pp. 1386-87 supra) separate weapons any one of which can defeat a cause of action. But some courts have made an effort to apply the test neutrally, setting forth the criteria with no analysis of how they were used in Cort. See, e.g., Lloyd v. Regional Transp. Auth., 548 F.2d 1277, 1284.87 (7th Cir. 1977); Rauch v. United Instruments, 405 F. Supp. $435,438-41$ (E.D. Pa. 1975), rev'd, 548 F.2d 452 (3d Cir. 1976). 
plaintiff."138 In Cannon the Seventh Circuit stated that it would assume arguendo that the plaintiff, a woman claiming sex discrimination in professional school admissions, was within the protections of Title IX.139 This statement seems disingenuous, since it is easy to see that Title IX was intended to protect women in the plaintiff's position..$^{\mathbf{1 4 0}}$ In approaching this threshold question in the civil rights context, the court should concentrate on determining the discrimination that Congress sought to end, the group it sought to protect, ${ }^{141}$ whether the plaintiff is a member of the group, and whether the plaintiff alleges precisely that discrimination. In many cases the language of the statute alone will be sufficient to answer these questions, ${ }^{142}$ although inquiry into legislative history may also be necessary. ${ }^{143}$ In making these determinations, the court may be influenced by the statute's broad purpose. ${ }^{144}$

Second, Cort asks whether there is "any indication of legislative intent, explicit or implicit, either to create such a remedy or to deny one." 140 In Cort the legislative silence on the matter was taken as

138. Cort v. Ash, 422 U.S. 66, 78 (1975).

139. Cannon v. University of Chicago, 559 F.2d 1077, 1080 (7th Cir. 1977), petition for cert. filed, 46 U.S.L.W. 3438 (Dec. 28, 1977) (No. 77-926).

140. The words of the statute are clear and unambiguous on this point: "in regard to admissions to educational institutions, this section [the prohibition on discrimination] shall apply ... to institutions of . . professional education." 20 U.S.C. $\$ 1681(a)(1)$ (Supp. V 1975) (emphasis added). The legislative history is also clear. The principal sponsor of the amendment that became Title IX, Senator Birch Bayh, said during the debates that the amendment "tries to speak directly in regard to women students who do want access to institutions." 118 CoNG. REc. 5813 (1972). He also called it "an important first step in the effort to provide for the women of America something that is rightfully theirs-an equal chance to attend the schools of their choice." Id. at 5808 (emphasis added).

141. Usually it will be clear what group Congress sought to protect. The question may be less clear under the Fourteenth Amendment, for example, where the number of "suspect" classes has proliferated. See G. Gunther, Cases and Materials on ConSTITUTIONAL LAw 763-85 (9th ed. 1975).

142. See, e.g., note 123 supra (discussing Title VI).

143. It appears that the Court has only once undertaken a major examination of the legislative history of a civil rights statute in the implication context to determine whether the plaintiff was within its intended ambit. Jones v. Alfred H. Mayer Co., 392 U.S. 409, 422.37 (1968) (arguing from legislative history of 42 U.S.C. $\$ 1982$ (1970) that that section was meant to protect black buyers from discriminatory private refusals to sell real estate).

144. The purpose inquiry was permitted to influence the search in Cort for evidence of whether the plaintiffs were among the statute's "especial" beneficiaries. Cort v. Ash, 422 U.S. 66, 80-82 (1975).

145. Id. at 78. It is somewhat inaccurate to pose the problem of implication primarily, or even largely, in terms of determining the legislative intent. When the legislative intent is clear, there is no need for a sophisticated test; such a test really only comes into use when the legislative history is silent. See Albert, supra note 3, at 452-56; Frankfurter, supra note 32, at 539. Cf. Wellington, Common Law Rules and Constitutional Double Standards: Some Notes on Adjudication, 83 YALE L.J. 221, 262 (1973) (when legislative history is silent, court must determine what legislature "would have decided" 
an indication that no private right should be implied. ${ }^{140}$ The Cannon court, too, found the legislative history silent and followed Cort in reading the legislative silence as supporting its conclusion that no private right of action existed.147 The Cannon court may well have been too hasty in deciding that the legislative history was silent. ${ }^{148}$

had it "addressed the issue"); Note, supra note 2, at 291 (court may be in better position than was legislature at time of enactment to assess need for private civil remedy). Indeed, the clearer the legislative intent, the less discretion is involved in the decision whether to imply a private right of action-and the less need there is for the other three parts of the Cort test. Cf. Barnes v. Converse College, 436 F. Supp. 635, 638 (D.S.C. 1977) (legislative intent to create private right was explicit, so no test for implication applied). 146. 422 U.S. at $82-84$.

147. 559 F.2d at 1081-82. The Cannon court blended the existence of what it called a "sophisticated" administrative remedy with Amtrak's expressio unius reasoning to infer a legislative intent not to permit alternative enforcement schemes. See pp. $1383-84 \&$ note 101 supra (discussing this inference).

148. There is at least some evidence that during the debates over the amendment that would become Title IX, some members of Congress were thinking in terms of suits by individuals. Senator Bayh, the amendment's chief sponsor, was asked whether in his view Title IX "means that a private school for girls, for the sake of argument, would have to accept men teachers, or vice versa?" He replied: "Someone would have to prove that they did discriminate against teachers [on the basis of sex] first." Asked whether a boys' prep school would have to hire women faculty members, Senator Bayh stated: "[I]f discrimination can be proven, the answer is 'Yes." 118 CoNG. REc. 5813 (1972) (Sens. Pell and Bayh) (emphasis added). Although Senator Bayh could have been referring in these remarks to the administrative review process within the Department of Health, Education and Welfare, his language seems more appropriate for the discussion of lawsuits. When discussing the power of administrative agencies, Senator Bayh spoke in terms of compliance with regulations rather than proof of discrimination. $I d$. at 5807 .

The Cannon court on rehearing also discussed the legislative history of the Civil Rights Attorney's Fees Award Act of 1976, Pub. L. No. 94-559, $\$ 2,90$ Stat. 2641 (to be codified at 42 U.S.C. $\$ 1988$ ), which by its terms provides for the discretionary award of attorney's fees to successful plaintiffs in "any action or proceeding to enforce" Title IX. The court found in the legislative history evidence that Congress at the time of the Act's enactment was aware of the first Cannon holding that Title IX did not create a private right of action and did not seek to overturn it. 559 F.2d at 1079-80. The same legislative history, however, also indicates that the Act's sponsors went out of their way to make clear that they were not endorsing the Cannon holding. Pressed repeatedly to state whether they intended through the Attorney's Fees Act to create a private right of action under 'Title IX, the Act's sponsors answered only with vague and ambiguous assurances and apparently tried to avoid either endorsing or opposing the Cannon result. Representative Drinan said that the Act would make "no change in the substantive preexisting law in this case before the body at this time. We accept preexisting law, whatever it is." Representative Railsback added:

I would simply like to point out that, as I understand it, it is clearly not the intent of Congress to create a new remedy, but that, rather, this bill would create a remedy only in the event that the courts should in the future determine that an individual may sue under the statutes.

And the bill does not authorize or statutorily grant any private right of action which does not now exist.

Representative Drinan said he concurred "completely." 122 CoNG. Rec. H12153 (daily ed., Oct. 1, 1976) (Reps. Drinan and Railsback). He then went on to say that the Act would cover "any action, including suits by individuals, instituted under title IX." Id. at H12159 (Rep. Drinan) (emphasis supplied). In short, although the legislative history makes clear that Congress did not attempt in enacting the Attorney's Fees Act to over- 
But even if correct, the panel should not have used the legislative silence as it did. Such an interpretation of legislative silence may make sense if a court is taking a restrictive view of implication, but it is by no means the only possible interpretation. ${ }^{149}$ In the civil rights cases the Court has found it unnecessary to search the legislative history for affirmative signs of intent to create a private right of action. The Court has focused instead on Congress's clear intention to grant the broadest possible protection to civil rights, ${ }^{150}$ and it has noted the difficulty of fulfilling that purpose without implication of private rights of action..$^{151}$ Title IX's clear intent, the protection of women in federally assisted educational programs, ${ }^{152}$ would be equally difficult to attain without a private right. ${ }^{153}$ Thus a court applying the second Cort criterion to a civil rights statute should seek to determine how a private right will contribute to enforcing the protections Congress intended to extend before deciding what weight to accord to legislative silence on the question of private rights. ${ }^{154}$

The third of Justice Brennan's Cort criteria asks whether it is "consistent with the underlying purposes of the legislative scheme to im-

turn the Cannon holding, it makes equally clear that the bill's sponsors took pains not to endorse the decision.

There is also support for the notion that a private right exists under Title IX in the legislative history of Section 504 of the Rehabilitation Act of 1973, as amended, 29 U.S.C. $\$ 794$ (Supp. V 1975). See Summary of the Committee Substitute [Amendment of Section 501], 120 Cong. REc. 30532, 30534 (1974) ("The section was patterned after, and is almost identical to, the antidiscrimination language of [Title VI] and [Title IX] .... [I]mplementation of section 504, which closely follows the models of the abovecited anti-discrimination provisions, would ... permit a judicial remedy through a private action.")

149. See, e.g., E. Levi, An Introduction to Legal Reasoning 57 (1949) ("It is not that the silence of Congress implies anything.")

150. This is similar to the "underiying purposes" inquiry of Cort v. Ash, 422 U.S. 66, 78 (1975).

151. See, e.g., Allen v. State Bd. of Elections, 393 U.S. 544, 556-57 (1969).

152. It seems safe to assume that Title IX, like Title VI, is intended as an effort to secure equality and is not merely intended to keep federal funds from becoming tainted with discriminatory usage. See note 123 supra (making argument for Title VI); 118 CoNc. REc. 5808 (1972) (Sen. Bayh) (Title IX intended to give women "an equal chance" in educational programs); Kuhn, Title IX: Employment and Athletics Are Outside HEW's Jurisdiction, 65 GEo. L.J. 49, 50-54, 56-62 (1976) (legislative history of Title IX makes clear that language was intended to have same meaning as parallel language of Title VI).

153. See pp. 1405-06 infra.

154. As Judge Bazelon has written of Title VI: "In the absence of strong legislative history to the contrary, the plain purpose of the statute is controlling. Here that purpose is clearly to eliminate discrimination in programs or activities benefitting from federal financial assistance." McGlotten v. Connally, 338 F. Supp. 448, 461 (D.D.C. 1972) (threejudge court). McGlotten held that contributions to a private organization that discriminated on the basis of race could not, consistent with Title VI, be made tax deductible. It may well be that under current law, the action would have been dismissed for lack of standing. See Simon v. Eastern Ky. Welfare Rights Organization, 426 U.S. 26, 63-64 (1976) (Brennan, J., concurring in part and dissenting in part). 
ply such a remedy for the plaintiff." ${ }^{155}$ Justice Brennan disposed of this criterion in a single paragraph, concluding that Congress's "underlying purpose" in enacting the statute in question was to deter corporations from spending money to influence the outcome of elections and that an implied private remedy "would not aid the primary congressional goal." 156 In a similarly conclusory manner, Cannon made hardly any attempt to defend Title IX's enforcement scheme as adequate, ${ }^{157}$ even though the agency charged with enforcing it challenged the scheme's sufficiency. ${ }^{158}$ Rather than focus on the relationship between an implied right of action and the substantive social policies embodied in the statute, ${ }^{150}$ the Cannon panel examined the relationship between the private right and the statutory enforcement scheme. ${ }^{150}$

Properly applied, the question of consistency under civil rights statutes would be treated much the same way as the question of legislative intent. A court should recognize the breadth of purpose of civil rights statutes and the likelihood that Congress did not intend the enforcement mechanism as a limitation on that purpose. ${ }^{101}$ In many cases involving civil rights, the court has expressly criticized the administrative enforcement mechanism as insufficient to carry out the congressional purpose. ${ }^{162}$ In Allen, for example, the inadequacy was apparent: there were too many jurisdictions for the At-

155. Cort v. Ash, 422 U.S. 66, 78 (1975).

156. Id. at 84 .

157. The panel did suggest that before private suits were permitted, the administrative scheme ought to be given "an opportunity to work." Cannon v. University of Chicago, 559 F.2d 1077, 1082 (7th Cir. 1977), petition for cert. filed, 46 U.S.L.W. 3438 (U.S. Dec. 28, 1977) (No. 77-926).

158. On rehearing, the Department of Health, Education and Welfare argued for the existence of a private right of action. 559 F.2d at 1080-82. The government also currently takes the position that a private right of action exists under Title VI. Supplemental Brief for the United States as Amicus Curiae at 23-24, Regents of the Univ. of Cal. v. Bakke, No. 76-811 (U.S. 1977); see note 123 supra. But at least as respects Title IX, the government's position has not been consistent. See, e.g., UNITEd STATEs Commission on Civic Rights, A Guide to Federal Laws Prohibiting Sex Discrimination 49 (1974) (advising those who feel they may have been discriminated against on basis of sex in program covered by Title IX to file complaint with HEW; no mention of possible private suits).

159. Justice Harlan suggested this test in Bivens v. Six Unknown Named Agents of the Fed. Bureau of Narcotics, 403 U.S. 388, 402 (1971) (Harlan, J., concurring) ("[I]n suits for damages based on violations of federal statutes lacking any express authorization of a damage remedy, this Court has authorized such relief where, in its view, damages are necessary to effectuate the congressional policy underpinning the substantive provisions of the statute.")

160. 559 F.2d at 1073-74.

161. More likely, here, as in Allen and other civil rights cases, the two remedies, administrative review and private litigation, are meant to complement, not to compete with, one another. See pp. 1389-91 \& note 136 supra.

162. E.g., Allen v. State Bd. of Elections, 393 U.S. 544, 556-57 (1969); Tunstall v. Brotherhood of Locomotive Firemen and Enginemen, 323 U.S. 210, 213 (1944); Steele v. Louisville \& N.R.R. Co., 323 U.S. 192, 205-06 (1944). 
torney General's staff to keep track of them all. ${ }^{163}$ The Attorney General, who argued in favor of a private right, readily conceded his office's inability to enforce the statute alone..$^{164}$

Similarly, there would appear to be too many educational programs receiving federal funds for the Department of Health, Education and Welfare singlehandedly to enforce Title IX, ${ }^{165}$ and in Cannon the Department argued in favor of a private right of action. ${ }^{166}$ The ultimate sanction the Department has against an offender under Title IX is to cut off federal funds, ${ }^{167}$ but the federal government has historically been reluctant to take such measures. ${ }^{168}$ Processing complaints

163. Allen v. State Bd. of Elections, 393 U.S. 544, 556-57 (1969).

164. Id. at 557 n.23. The Court called the Attorney General's support of the proposition that a private right should be implied "significant."

165. There were 20,318 school districts and colleges told by the Department to file acceptable compliance statements by September 30, 1976. By March 15, 1977, only 6,742 had done so. School Law News, at 3 (March 18, 1977). See Shelton \& Berndt, supra note 3 , at $1138-49,1158$ (extensive intervicws and correspondence with HEW staff indicate difficulties of enforcement); Commentary, supra note 11 , at 418 (due to large number of complaints, enforcement "may be impossible" without private remedy).

166. Cannon v. University of Chicago, 559 F.2d 1077, 1080-82 (7th Cir. 1977), petition for cert. filed, 46 U.S.L.W. 3438 (U.S. Dec. 28, 1977) (No. 77-926).

167. See 20 U.S.C. $\$ 1682$ (Supp. V 1975). Although 45 C.F.R. $\$ \$ 80.9-81.131$ (1976) set regulations for hearings prior to a cutoff of funds, it is clear that the provision is directed toward permitting a recipient of funds to raise an objection. It says nothing about the right of a victim of discrimination, except by the filing of an initial complaint and sometimes as an amicus, to participate in the hearing process. See id. $\$ 81.23$. It was a similar deficiency in the welfare review procedures that led the Supreme Court to permit welfare recipients to bypass the administrative process and bring private suits. Rosado v. Wyman, 397 U.S. 397, 406, 420 (1970). See also 118 CoNc. Rec. 5807 (1972) (Sen. Bayh) (purpose of administrative review procedures under Title IX to protect recipients from unfair cutoff of funds).

168. The federal government's reluctance to cut off federal funds may be traced to political pressures that mounted on the Department of Health, Education and Welfare when it first received the authority under Title VI to cut off federal funding. See A. Wolk, The Presidency and Black Civil Rights 140-42, 147-53 (1971). Even when noncompliance shows up on a Title VI review, the Department has been hesitant to take the drastic action of terminating a program's funding. See 3 UNITEd STATEs Commission on Civil Rights, The Federal Civil Rights Enforcement Effort-1974, at 244-64 (1975) [hereinafter cited as CiviL RIGHTs 1974]. In fact, the Department has sometimes had to be ordered by federal courts to require compliance with civil rights statutes. See School Law News, at 1-2 (Jan. 6, 1978) (settlement of major cases); Karst, supra note 89, at 1061-62 (citing cases). The experience under $\S 504$ of the Rehabilitation Act of 1973, 29 U.S.C. $\$ 794$ (Supp. V 1975), which forbids discrimination on the basis of handicap in federally funded programs, has been equally disappointing to civil rights advocates. The Department did not issue final compliance regulations until ordered to do so by a federal court, more than three years after the Act's enactment. Cherry v. Mathews, 419 F. Supp. 922 (D.D.C. 1976). Title IX complainants may face the additional obstacle that many regional offices are not really very interested in its enforcement. Shelton \& Berndt, supra note 3, at 1139 n.Ill (quoting high-ranking Department officials).

Implying a private right of action does not require that the administrative agency be unwilling or hesitant to carry out its statutory enforcement duties. But the difficulties already posed by the sheer number of programs to be monitored may be exacerbated in the face of possible administrative intransigence. 
through the Office of Civil Rights is an arduous and time-consuming procedure. ${ }^{109}$ Moreover, merely ceasing to fund a discriminatory program will do nothing to remedy the damage existing violations have already done to prospective plaintiffs. ${ }^{170}$ These difficulties alone should make clear that implication of a private right is certainly consistent with Congress's broad purpose in enacting Title IX. ${ }^{171}$ Thus a federal court seeking to determine whether to permit a private right of action under a civil rights statute should focus on whether, given its broad purpose, the statutory remedy alone is clearly adequate.

The final question posed in Cort was whether the plaintiff's cause of action is "one traditionally relegated to state law, in an area basically the concern of the States."172 In Cort Justice Brennan emphasized that "[c]orporations are creatures of state law" and that as a general rule "state law will govern the internal affairs of the corporation." 173 Thus the Court held that it was reasonable to expect the plaintiff to pursue his remedy under state law. ${ }^{174}$ The Cannon court assumed arguendo that the cause of action asserted did not displace any traditional state law remedies. ${ }^{175}$ Causes of action to protect civil rights are historically not the province of state governments. ${ }^{170}$ Civil rights laws developed initially as a response to discriminatory state action, ${ }^{177}$ and a number of federal causes of action to protect civil

169. Note, supra note 136, at 212-21. In its first few years of enforcing Title IX, the Department has been particularly slow to resolve complaints. CiviL Rigirs 1974, supra note 168, at 124-27, 306-08; School Law Ncws, at 1,5 (June 10, 1977); id. at 7.8 (July 22, 1977); id. at 6.7 (Nov. 11, 1977). For example, of 127 Title IX complaints received in 1974, only 27 were resolved. 40 Fed. Reg. 24149 (1975). Department officials admitted in 1974 that it could take up to 18 months to resolve a complaint. Shelton \& Berndt, supra note 3 , at 1142 . Although the Department has recently promised a crackdown on Title IX offenders, see, e.g., School Law News, at 3 (March 18, 1977); id. at I (April 1,1977 ), it agreed in December 1977 only to "try" to eliminate its backlog of 3,000 complaints under Title IX and other statutes by September 30, 1979. Id. at 1 (Jan. 6, 1978).

170. "Without the recognition of a private cause of action under [Title IX], individual litigants who suffered from non-employment related sex discrimination . . would be left with no remedy for the personal injury which they suffered to their education." Piascik v. Cleveland Museum of Art, 426 F. Supp. 779, 780 n.l (N.D. Ohio 1976).

171. Id.

172. Cort v. Ash, 422 U.S. 66, 78 (1975).

173. Id. at 84 .

174. Id. at 85 .

175. Cannon v. University of Chicago, 559 F.2d 1077, 1080 (7th Cir. 1977), petition for cert. filed, 46 U.S.L.W. 3438 (U.S. Dec. 28, 1977) (No. 77-926).

176. In the early post-Civil War period, there was apparently a general expectation that state courts would enforce the civil rights of the freedmen against discriminatory state action. Much early civil rights legislation was a response to the courts' unwillingness -to say nothing of their inability-to do so. See C. Pritchetr, The American Constitution 738 (2d ed. 1968).

177. W. DuBois, Black Reconsiruction in America 163-79, 628-30 (1935); C. Pritchett, supra note 176, at 739-42; see C. WOODWARD, THE BURDEN OF SOUTHERN History $69-87$ 
rights against encroachment by private parties exist as well. ${ }^{178}$ Thus even if state law afforded a remedy, it would not be one "traditionally" in the province of the states. Given this history, a court deciding whether to imply a private right under a civil rights statute should not pause long over this criterion.

The proper application of Cort to civil rights statutes can be summarized briefly. First, in determining whether the plaintiff's class is intended to receive "especial benefit" from the legislation, the court should determine what group Congress sought to protect from what sort of discrimination, whether the plaintiff is a member of that group, and whether the plaintiff alleges the right sort of discrimination. Second, the court should take Congress's "broad purpose" in enacting the statute as guiding its interpretation of whether private actions should be precluded in the face of legislative silence. Third, the court should also focus on the broad purpose of civil rights legislation and consider the extent to which implication of a private right would aid in accomplishing that purpose before deciding whether a private right is "consistent with the underlying purposes of the legislative scheme." The court should further seek to determine whether the existing enforcement scheme appears adequate to protect the plaintiff's rights, bearing in mind that the scope of the rights was not intended to be dependent on administrative discretion. Finally, the court should assume that the cause of action will not displace a traditional state law remedy, because remedies for violation of civil rights are traditionally at federal law.

\section{Conclusion}

The restrictive manner in which the Supreme Court tested for a private right of action in Cort $v$. Ash is not appropriate in the field of civil rights law. The Cort criteria should, in this field, be applied in the sympathetic fashion characteristic of the search for private rights of action under civil rights statutes. Properly applied, the Cort criteria would lead to the conclusion that private rights of action exist under Title IX and other civil rights statutes.

(1960). An extensive examination of the legislative history of the first federal civil rights laws may be found in R. Berger, Government bY JUdiciary 22-36 (1977).

178. See, e.g., 42 U.S.C. $\$ 1982(1970)$, discussed at note 63 supra (providing cause of action against private party refusing on basis of race to convey real property); Civil Rights Act of 1964, Title VII, as amended, 42 U.S.C. $\$ \$ 2000 \mathrm{e}$ to $2000 \mathrm{c}-15$ (1970 \& Supp. $\mathrm{V}$ 1975) (providing private cause of action in some circumstances against private cmployer or union discriminating on basis of race). 